\title{
Inhibition of astrocyte proliferation and binding to brain tissue of anticardiolipin antibodies purified from lupus serum
}

\author{
Kuang-Hui Sun, Wu-Tse Liu, Chang-Youh Tsai, Tang-Shueen Liao, Whu-Mei Lin,
} Chia-Li Yu

\begin{abstract}
Polyclonal anticardiolipin antibodies purified from pooled serum samples of patients with systemic lupus erythematosus were shown to have inhibitory effects on cultured normal rat brain astrocytes (RBA-1 cells). Anticardiolipin antibodies at concentrations from 50 to 200 $\mu \mathrm{g} / \mathrm{ml}$ inhibited the $\left[{ }^{3} \mathrm{H}\right]$ thymidine incorporation of RBA-1 cells in a dose dependent manner after three days of culture. A kinetic study showed that anticardiolipin antibodies $(100 \mu \mathrm{g} / \mathrm{ml})$ maximally inhibit the proliferation of RBA-1 cells $(20.6(5 \cdot 1) \%$ of the control value) after incubation for one day. In contrast, human $\gamma$ globulin $(100 \mu \mathrm{g} / \mathrm{ml})$ had no effect on these cells. In the presence of anticardiolipin antibodies $(100 \mu \mathrm{g} / \mathrm{ml})$, the RBA-1 cells attached to the bottom of wells became spherical and the expression of glial fibrillary acidic protein in the cytoplasm was slightly reduced. Using 3,3'-dihexyloxacarbocyanine iodide as an indicator, anticardiolipin antibodies depolarised the membrane potential of RBA-1 cells after one day of culture. In addition, the percentage binding of RBA-1 cells with anticardiolipin antibodies was greater than with $\gamma$ globulin as determined by flow cytometric analysis. Immunofluorescence staining of brain tissue from BALB/c mice with anticardiolipin antibodies was noted in the corpus callosum, the cellular zone near the corpus callosum, and cells scattered in brain tissue. These results suggest that anticardiolipin antibodies have an inhibitory effect on brain cells and elicit thrombus formation in brain vessels, which plays a part in neuropsychiatric lupus.
\end{abstract}

Neuropsychiatric manifestations are common in patients with systemic lupus erythematosus (SLE). More than $25 \%$ of these patients develop central nervous system disease in the first two years after the diagnosis of SLE. Microscopic studies of the brains of patients with SLE who died have emphasised the presence of widely scattered microinfarcts and a non-inflammatory vasculopathy. True vasculitis with inflammatory cells invading vessel walls and fibrinoid necrosis are rarely seen in the nervous system of patients with SLE, however. ${ }^{12}$ It is believed that autoantibodies reactive with the cell membrane in the circulation or cerebrospinal fluid, such as antilymphocyte, ${ }^{34}$ antineuronal, ${ }^{56}$ antineurofilament, ${ }^{78}$ or antiglycolipid ${ }^{9}$ antibodies parti- cipate in the development of central nervous system lupus:

Many reports ${ }^{10-19}$ have implied an association between anticardiolipin antibodies and various neurological diseases including central nervous system lupus, the myelopathy of lupoid sclerosis and Degos's disease, Guillain-Barré syndrome, migraine, chorea, and seizures. Using liposome or micelle purified anticardiolipin antibodies, Misra $e t a l^{20}$ and $\mathrm{Yu}$ et $a l^{2 \mathrm{I}}$ showed that anticardiolipin antibodies could react with and disturb the functions of lectin activated lymphocytes and neutrophil phagocytosis. As brain tissue contains a higher proportion of phospholipids than other organs, we speculate that anticardiolipin antibodies may have a biological effect on nerve tissue and may derange its function once the autoantibodies pass into the brain. In this study, anticardiolipin antibodies were purified from serum samples from patients with SLE and the effects of these antibodies on normal rat brain astrocytes and their binding capacity with brain tissue were investigated.

\section{Materials and methods}

PURIFICATION OF ANTICARDIOLIPIN ANTIBODIES WITH CARDIOLIPIN MICELLES

The purification of anticardiolipin antibodies followed the method described by Harris et $a l^{22}$ with some modifications. ${ }^{21}$

\section{SUBCULTURE OF NORMAL RAT BRAIN} ASTROCYTES

The RBA-1 cells were established by continuous passaging and enriching of cultures of the brain cells of three day old rats (JAR-2, F-51) for four years. The cells were cultured in $10 \%$ fetal bovine serum in RPMI 1640 without antibiotics. The RBA-1 cells were identified by the following properties: $(a)$ no tumourigenicity when inoculated into nude mice; (b) $71 \cdot 5 \%$ of the cells maintained diploid chromosomes in karyotype analysis; $(c)$ the presence of glial fibrillary acidic protein in the cytoplasm detected by an immunochemical method; and (d) contact inhibition observed during long term culture. ${ }^{23-25}$

$\left[{ }^{3} \mathrm{H}\right]$ THYMIDINE INCORPORATION OF RBA-1 CELLS RBA-1 cells $\left(100 \mu \mathrm{l} ; 1 \times 10^{5} / \mathrm{ml}\right)$ were placed in flat bottomed microwells in triplicate. Anticardiolipin antibodies $(100 \mu \mathrm{l}$ of 100,200 , and $400 \mu \mathrm{g} / \mathrm{ml}$ solutions) were added to the wells. In the control wells, 0.1 ml RPMI 1640 or the 
corresponding concentration of human $\gamma$ globulin (Cohn fraction II, Sigma Chemical, St Louis, MO, USA) was added instead of anticardiolipin antibodies. The mixture was incubated at $37^{\circ} \mathrm{C}$ in $5 \%$ carbon dioxide $/ 95 \%$ air for 68 hours followed by four hours of pulsing with $18.5 \mathrm{kBq}$ methyl $\left[{ }^{3} \mathrm{H}\right]$ thymidine (specific activity $2 \cdot 5 \times 10^{5} \mathrm{MBq} / \mathrm{mmol}$; NEN, Boston, MA, USA). The cells were harvested and the radioactivity measured by a $\beta$ counter.

\section{ESTIMATION OF MEMBRANE POTENTIAL OF} INDIVIDUAL RBA-1 CELLS

The membrane potential was measured by the method of Shapiro et al. ${ }^{26}$ The indicator dye used was 3, 3'-dihexyloxacarbocyanine iodide (Eastman Kodak, Rochester, NY, USA). The RBA-1 cells $\left(5 \times 10^{5} / \mathrm{ml}\right)$ were cultured and reacted with $100 \mu \mathrm{g} / \mathrm{ml}$ anticardiolipin antibodies (or $100 \mu \mathrm{g} / \mathrm{ml}$ of $\gamma$ globulin as control) in plastic petri dishes for one day before harvesting. The attached cells were collected by incubation with $0.125 \%$ trypsin-1 mM EDTA in phosphate buffered saline solution ( $\mathrm{pH} 7 \cdot 2)$ for five minutes and the membrane potentials of these cells were estimated by EPICS C flow cytometry (Coulter Electronics, Hialeah, Miami, FL, USA) with excitation at $488 \mathrm{~nm}$.

BINDING OF RBA-1 CELLS WITH ANTICARDIOLIPIN ANTIBODIES

RBA-1 $\left(1 \times 10^{6}\right.$ cells $\left./ 0 \cdot 1 \mathrm{ml}\right)$ were reacted with $0.1 \mathrm{ml}$ anticardiolipin antibodies $(400 \mu \mathrm{g} / \mathrm{ml})$ or human $\gamma$ globulin $(400 \mu \mathrm{g} / \mathrm{ml})$ in an ice bath for 30 minutes. After two washes with Hanks's balanced salt solution the cells were stained with FITC conjugated goat antihuman IgG in an ice bath for another 30 minutes. After washing with Isoton II (Coulter), the percentage and fluorescence intensity of RBA-1 cells were measured by EPICS C flow cytometry.

\section{DETECTION OF GLIAL FIBRILLARY ACIDIC} PROTEIN IN RBA- 1 CELLS

The detection of glial fibrillary acidic protein was carried out by the indirect immunofluorescence method reported by Jou and Akimoto $^{24}$ with some modifications. RBA-1 cells $\left(1.5 \times 10^{5} / \mathrm{ml}\right)$ were cultured on coverslips and became attached after overnight incubation. Anticardiolipin antibodies, RPMI, or $\gamma$ globulin were then added to the individual cultures. After 18 hours incubation the cells were fixed in $70 \%$ ethanol (at $4^{\circ} \mathrm{C}$ ) for one hour and coated with $0.5 \%$ bovine serum albumin to reduce the non-specific binding with proteins. The coverslips were then incubated in a moist chamber with mouse monoclonal antibodies to glial fibrillary acidic protein (1:200 dilution in phosphate buffered saline) (BioMakor, Israel) for one hour. After rinsing with phosphate buffered saline, the coverslips were stained with FITC conjugated goat antimouse IgG (Jackson Immunoresearch Laboratories, West Grove, PA, USA) at 1:20 dilution for 30 minutes and rinsed again with phosphate buffered saline. The cells were examined with a fluorescence microscope.
IMMUNOFLUORESCENCE STAINING OF MOUSE BRAIN TISSUE WITH ANTICARDIOLIPIN ANTIBODIES AND ANTIBODIES TO GLIAL FIBRILLARY ACIDIC PROTEIN

BALB/c mouse brains were cut cryogenically and stained by indirect immunofluorescence. Briefly, $5 \mu \mathrm{m}$ thick cryostat sections of brain tissue were first incubated with anticardiolipin antibodies $(100 \mu \mathrm{g} / \mathrm{ml})$, or 1:200 diluted mouse antibodies to glial fibrillary acidic protein, for one hour at room temperature. Human $\gamma$ globulin $(100 \mu \mathrm{g} / \mathrm{ml})$ was the control protein. After washing with phosphate buffered saline, FITC conjugated antihuman IgG (or FITC conjugated antimouse IgG for glial fibrillary acidic protein stain) was added and incubated for another 30 minutes. The slides were rinsed, mounted, and examined under a fluorescence microscope.

\section{STATISTICAL ANALYSIS}

The results are given as mean (SD) for the whole study. Statistic significance was analysed by the non-parametric Wilcoxon signed rank test.

\section{Results}

EFFECT OF ANTICARDIOLIPIN ANTIBODIES ON THE GROWTH OF RBA-1 CELLS

The proliferation of RBA-1 cells was evaluated by the incorporation of $\left[{ }^{3} \mathrm{H}\right]$ thymidine into the cells. Figure 1 shows that the inhibition of proliferation of RBA-1 cells by anticardiolipin antibodies was dose dependent and greater than that by human $\gamma$ globulin. Kinetic studies showed that anticardiolipin antibodies $(100 \mu \mathrm{g} /$ $\mathrm{ml}$ ) inhibited the proliferation of RBA-l cells $(20.6(5 \cdot 1) \%$ of the control) maximally after 24 hours of interaction whereas human $\gamma$ globulin had no significant effect on these cells (fig 2).

EFFECT OF ANTICARDIOLIPIN ANTIBODIES ON THE EXPRESSION OF GLIAL FIBRILLARY ACIDIC PROTEIN IN RBA-1 CELLS

The specific marker for differentiated astrocytes

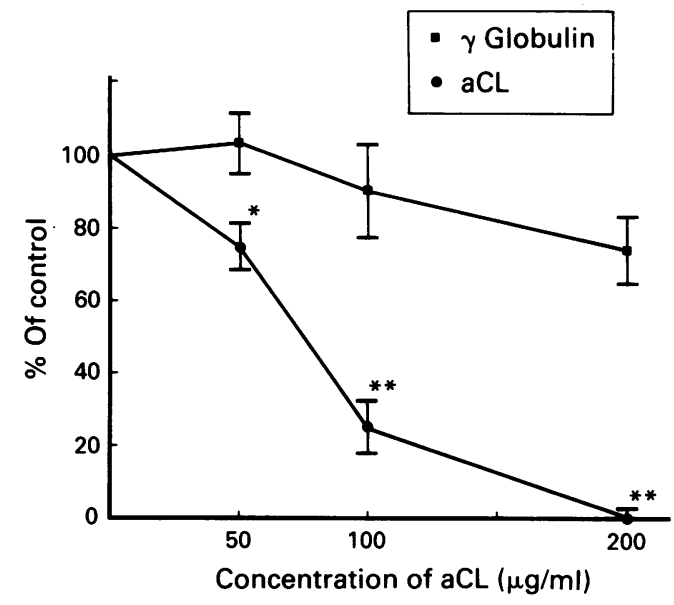

Figure 1 Dose dependent suppression of anticardiolipin antibodies $(a C L)(O)$ and human $\gamma$ globulin (D) on the $\left[{ }^{3} \mathrm{H}\right]$ thymidine incorporation of $R B A-1$ cells. ${ }^{*} p<0 \cdot 05$ $* * p<0.001$. 
Figure 2 Comparison of proliferation inhibition of $R B A-1$ by $100 \mu \mathrm{g} / \mathrm{ml}$ anticardiolipin antibodies $(a C L)$ and human $\gamma$ globulin after incubation for one, three, and five days.
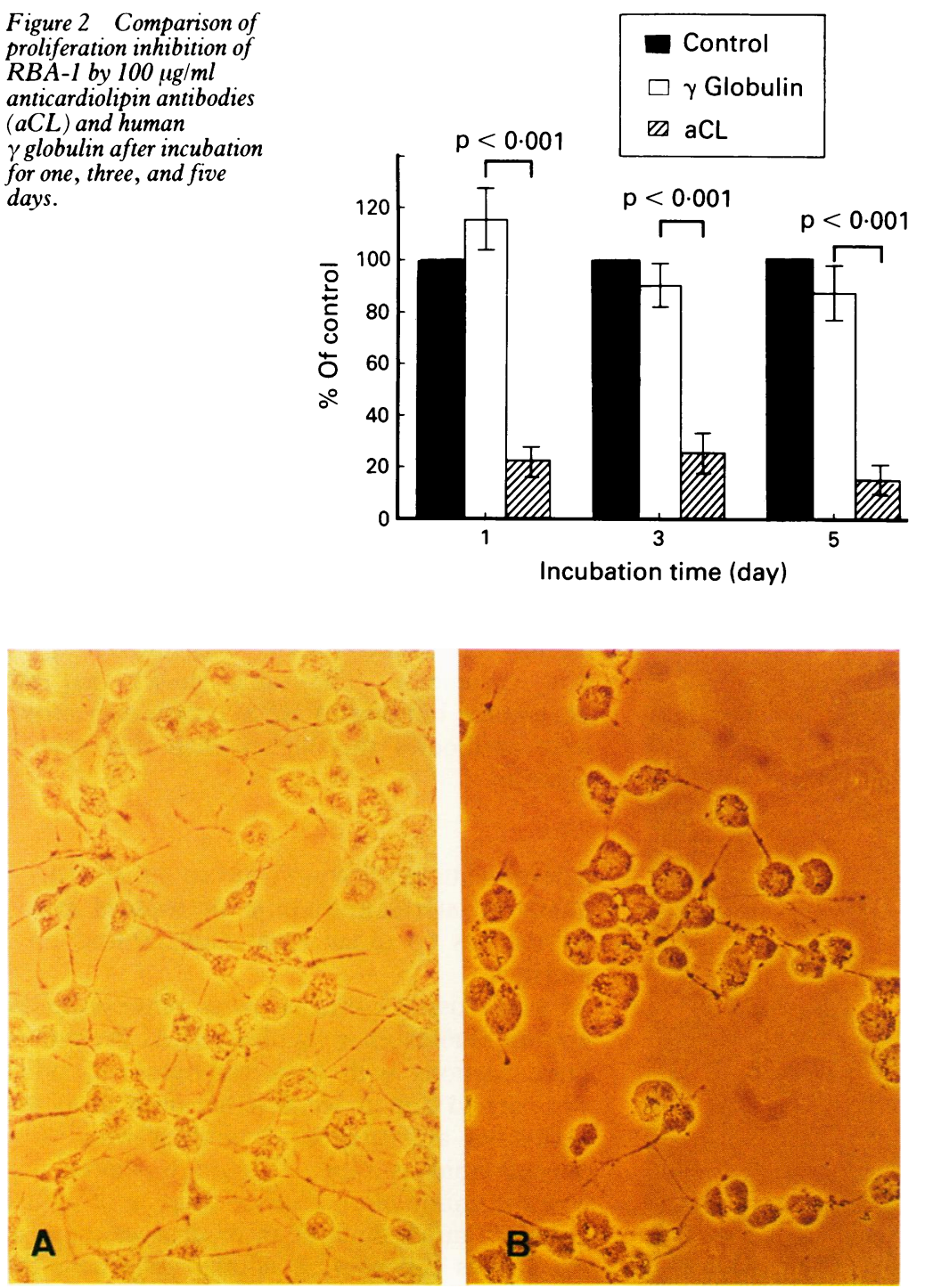

Figure 3 Morphological changes of RBA-1 cells after incubation with $100 \mu \mathrm{g} / \mathrm{ml}$ human $\gamma$ globulin $(A)$ and $100 \mu \mathrm{g} / \mathrm{ml}$ anticardiolipin antibodies $(B)$ for one day (original magnification $\times 400)$. The cells firmly attached to the glass surface with multiple extended dendrites $(A)$. These cells became rounded and the dendrites decreased or even disappeared in some cells after incubation with anticardiolipin antibodies $(B)$.
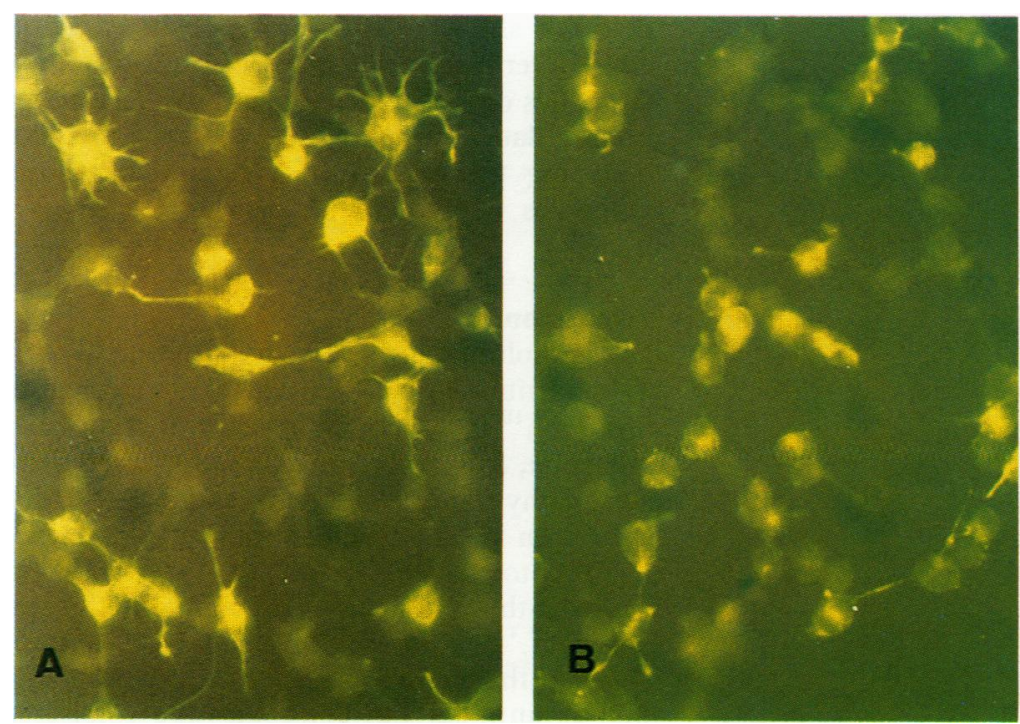

Figure 4 Changes in fluorescence intensity of glial fibrillary acidic protein in the cytoplasm of $R B A-1$ cells after incubation with $100 \mu \mathrm{g} / \mathrm{ml}$ human $\gamma$ globulin $(A)$ or anticardiolipin antibodies $(B)$ for one day (original magnification $\times 400)$. The $R B A-1$ cells were cultured in coverslips, fixed in $70 \%$ ethanol, and stained with mouse monoclonal antibodies to glial fibrillary acidic protein and FITC conjugated goat antimouse IgG antibodies. is glial fibrillary acidic protein in the cytoplasm. To determine if anticardiolipin antibodies interfere with the expression of glial fibrillary acidic protein, the immunofluorescence staining of glial fibrillary acidic protein in RBA-1 cells was evaluated after two days of incubation with anticardiolipin antibodies or $\gamma$ globulin. Figure 3 shows that in the presence of anticardiolipin antibodies $(100 \mu \mathrm{g} / \mathrm{ml})$ the cells underwent conspicuous morphological changes, but the concentration of glial fibrillary acidic protein in the cytoplasm decreased, as shown by the faint fluoresence in the cells (fig 4). Unequal expression of cytoplasmic glial fibrillary acidic protein in the individual astrocytes and the presence of cells with scanty dendrites in fig 4 give the small differences in cytoplasmic fluorescence. Whether the anticardiolipin antibodies are suppressing glial fibrillary acidic protein in RBA-1 needs further investigation.

EFFECTS OF ANTICARDIOLIPIN ANTIBODIES ON THE MEMBRANE POTENTIAL OF INDIVIDUAL RBA-1 CELLS

To test whether the inhibitory effects of the anticardiolipin antibodies on RBA-1 cells were mediated through their membrane effect, the membrane potential of these cells was evaluated by flow cytometry after incubation with the antibodies for various times. Depolarisation of
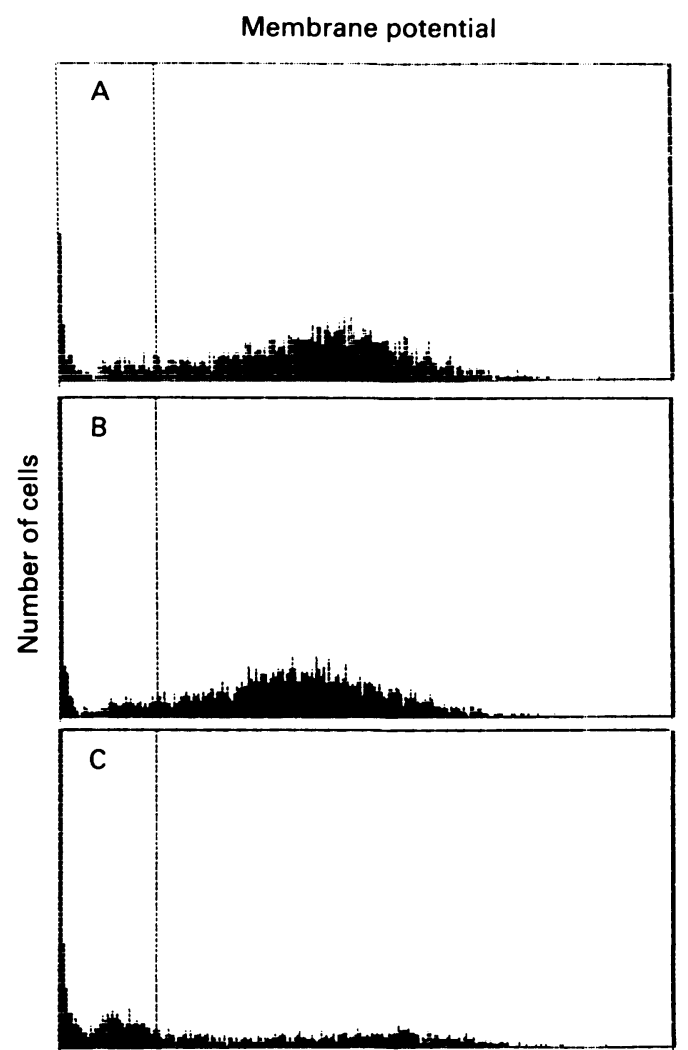

Fluorescence intensity

Figure 5 Changes in membrane potential of RBA-1 cells measured by flow cytometry after incubation with different reagents for two days. $(A) R B A-1$ incubated with medium: positive cells $67 \cdot 11 \%$, mean fluorescence intensity $110 \cdot 77$. (B) RBA-1 incubated with $100 \mu \mathrm{g} / \mathrm{ml}$ human $\gamma$ globulin: positive cells $60.47 \%$, mean fluorescence intensity 102.85. (C) $R B A-1$ incubated with $100 \mu g / m l$ anticardiolipin antibodies: positive cells $26 \cdot 22 \%$, mean fluorescence intensity $63 \cdot 19$. 

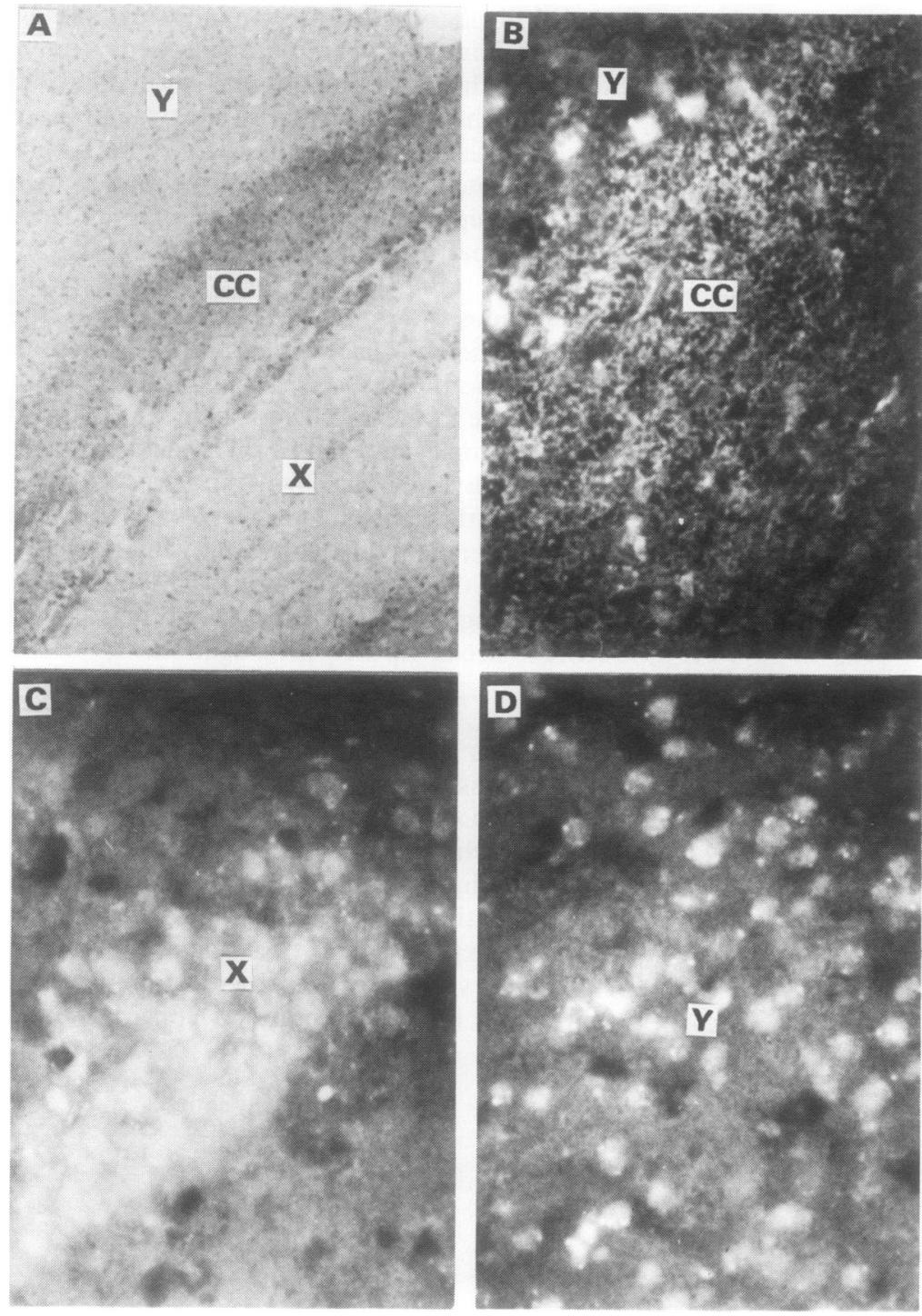

Figure 6 Immunofluorescence of $B A L B / c$ mouse brain stained with anticardiolipin antibodies. (A) Haematoxylin stain of mouse brain section: $C C$ is the corpus callosum, $X$ is $a$ cellular zone near the corpus callosum, and $Y$ is another area near the corpus callosum. (B) Immunofluorescence stain of corpus callosum. (C) Immunofluorescence stain of cellular $z o n e$. (D) Immunofluorescence stain of the cells scattered in area $Y$.
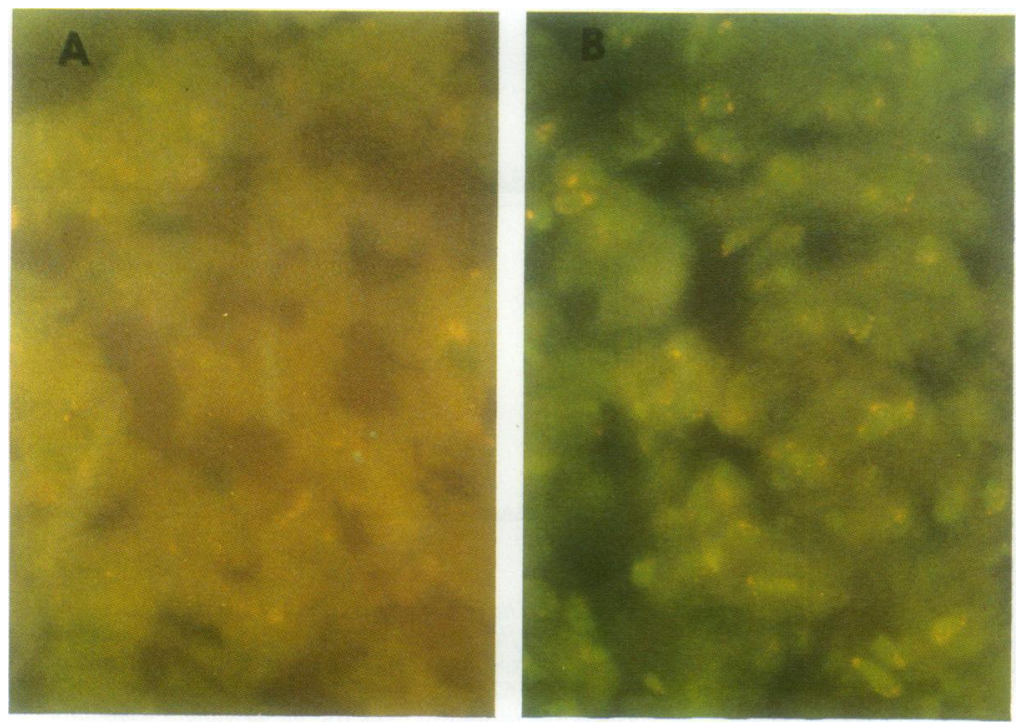

Figure 7 Immunofluorescence stain of $B A L B / c$ mouse brain tissue with $(A)$ human $\gamma$ globulin $(100 \mu \mathrm{g} / \mathrm{ml})$ and $(B)$ anticardiolipin antibodies $(100 \mu \mathrm{g} / \mathrm{ml})$. The localisation of the brain tissue is in the $Y$ area as shown in fig 6.
Binding of RBA-1 cells with anticardiolipin antibodies (100 $\mu \mathrm{g} / \mathrm{ml})$ and human $\gamma$ globulin $(100 \mu \mathrm{g} / \mathrm{ml})$

\begin{tabular}{lll}
\hline & \multicolumn{2}{c}{ Percentage binding of RBA-1 with } \\
\cline { 2 - 3 } & $\gamma$ Globulin & $\begin{array}{l}\text { Anticardiolipin } \\
\text { antibodies }\end{array}$ \\
\hline Experiment 1 & $1 \cdot 84(43 \cdot 34)$ & $9 \cdot 06(48 \cdot 25)$ \\
Experiment 2 & $3 \cdot 16(101 \cdot 31)$ & $9.42(110 \cdot 16)$ \\
Experiment 3 & $2 \cdot 37(90 \cdot 16)$ & $8 \cdot 72(108 \cdot 30)$
\end{tabular}

${ }^{*}$ Values in parentheses are the mean fluorescence intensity measured by flow cytometry.

the RBA-l cells was noted in the presence of anticardiolipin antibodies $(100 \mu \mathrm{g} / \mathrm{ml})$ in one and two day cultures, whereas no distinct change could be found in the culture with human $\gamma$ globulin and RPMI 1640 (fig 5). In another experiment, the binding of anticardiolipin antibodies $(100 \mu \mathrm{g} / \mathrm{ml})$ or $\gamma$ globulin $(100$ $\mu \mathrm{g} / \mathrm{ml}$ ) with $\mathrm{RBA}-1$ cells was measured by flow cytometry. The table shows that the percentage binding of RBA-1 with anticardiolipin antibodies was higher than that with $\gamma$ globulin.

IMMUNOFLUORESCENCE STAINING OF MOUSE BRAIN BY ANTICARDIOLIPIN ANTIBODIES AND ANTIBODIES TO GLIAL FIBRILLARY ACIDIC PROTEIN

As brain tissue contains many phospholipids, immunofluorescence staining of $\mathrm{BALB} / \mathrm{c}$ mouse brain sections with anticardiolipin antibodies was carried out to see whether anticardiolipin antibodies are capable of binding with these phospholipid epitopes. Figure 6 shows that positive immunofluorescence staining of mouse brain by anticardiolipin antibodies was seen in the corpus callosum, a cellular zone near the corpus callosum, and nerve cells scattered in other portions of the brain. In contrast, negligible fluorescence was found in the stain with human $\gamma$ globulin (fig 7). In the immunofluorescence staining of glial fibrillary acidic protein, positive results were also found in the corpus callosum and other areas of the brain (data not shown). In contrast, cryosections of mouse liver were not stained by anticardiolipin antibodies or antibodies to glial fibrillary acidic protein (data not shown) with the same method, indicating the high affinity of anticardiolipin antibodies with the brain tissue.

\section{Discussion}

Anticardiolipin antibodies are found in $22-70 \%$ of patients with SLE with neurological disorders, ${ }^{10}$ including focal cerebral and ocular ischaemia, transverse myelopathy, peripheral neuropathy, and movement and seizure disorders. In most instances these disorders are thought to be the result of thrombosis or vasculopathy induced by immune complexes. ${ }^{2}$ 12-15 Several workers have shown, however, that membrane reactive autoantibodies such as antineuronal antibodies are correlated with neuropsychiatric disorders of SLE. Bluestein $e t a l^{27}$ and Minota $e t a l^{28}$ found that integrins and heat shock proteins (hsp90) were potentially important membrane target mol- 
ecules for antineuronal and lymphocytotoxic antibodies in patients with neuropsychiatric lupus.

In addition to these observations there is some evidence that anticardiolipin antibodies also react with many types of activated cells in cell membranes. Khamashta $e a^{29}$ showed that purified anticardiolipin antibodies bound to phosphatidylethanolamine, phosphatidylserine, and phosphatidylinositol epitopes expressed on the freeze thawed platelets and red blood cells. Schorer $e t a l^{30}$ found that liposome purified anticardiolipin antibodies selectively inhibited prostacyclin release from thrombin activated endothelial cells. Misra $e t a l^{21}$ and $\mathrm{Yu}$ et $a l^{22}$ showed that affinity purified anticardiolipin antibodies suppressed the proliferation of phytohaemagglutinin activated peripheral lymphocytes and phagocytosis of neutrophils. Dostal-Johnson et $a l^{31}$ found that serum samples from patients with lupus anticoagulant contained antibodies against phosphatidylserine, cardiolipin, phosphatidylinositol, phosphatidylglycerol, and phosphatidylethanolamine. Brain tissue contains a high proportion of phospholipids and may become the target of anticardiolipin antibodies, especially in patients with SLE.

It is possible that the blood-brain barrier is constructed by microvascular endothelial cells and astrocytes. ${ }^{32}$ Functionally, this structure prohibits noxious substances such as autoantibodies from entering brain tissue. Although Lolli et $a l^{19}$ found that the local synthesis of anticardiolipin antibodies within the central nervous system was possible in patients with multiple sclerosis, neurosyphilis, or GuillainBarré syndrome, a simultaneous occurrence of anticardiolipin antibodies in the cerebrospinal fluid and serum of patients with SLE suggests that anticardiolipin antibodies may diffuse from serum to the central nervous system through a damaged blood-brain barrier. ${ }^{33}$

In an attempt to further understand the pathological part played by anticardiolipin antibodies on the central nervous system lesions of SLE, normal rat astrocytes were used as target cells. We showed that micelle purified anticardiolipin antibodies in serum samples from patients with SLE exerted suppressive effects on these cells in a dose dependent manner. This observation has not been reported elsewhere. The inhibitory effect of anticardiolipin antibodies on normal rat brain astrocytes is important as about $75 \%$ of patients with neuropsychiatric SLE have blood-brain barrier damage. ${ }^{34} 35$ When RBA-1 cells were incubated with anticardiolipin antibodies, the astrocytes became spherical in appearance and the cell membrane depolarised. It appears that anticardiolipin antibodies derange the structure and function of the blood-brain barrier, probably through their membrane effect. ${ }^{21}$ Once the blood-brain barrier is damaged, noxious substances, including cytotoxic antibodies, can access the brain tissue causing neuropsychiatric disorders. In addition, direct binding of anticardiolipin antibodies to the cell membranes of RBA-1 cells, though only slight (table), was also seen in this study. This binding may interfere with the signal transduction of the cells. The epitope(s) on the surface membrane of RBA-1 cells for anticardiolipin antibody binding and the real mechanism for the interference of signal transduction after autoantibody binding were not investigated in this work.

Another interesting observation in this study is that anticardiolipin antibodies bound to brain tissue but not to liver tissue. It seems that anticardiolipin antibodies selectively attack brain tissue and elicit neuropsychiatric lesions in SLE in addition to non-specific thrombus formation in the blood vessels. The tissue specific property of other autoantibodies in SLE has been shown by the selective renal damage caused by antibodies to double stranded DNA. ${ }^{36}$ Although we did not identify the target cells of the anticardiolipin antibodies in the brain, we noted that the nerve fibres and possibly glial cells in the corpus callosum, nerve cells in the cellular zone near the corpus callosum, and sporadic nerve cells in other brain areas were all positively stained by anticardiolipin antibodies (fig 6). Whether anticardiolipin antibodies cross react with antineuronal, antilymphocyte, antiglycolipid, or antineurofilament antibodies needs further investigation.

In conclusion, we found that anticardiolipin antibodies exerted inhibitory effects on normal rat astrocytes (blood-brain barrier damage) and bound directly to nerve fibres and nerve cells in the brain. This dual effect of anticardiolipin antibodies leads us to suggest that anticardiolipin antibodies as autoantibodies to neural membranes play an important part in the pathogenesis of neuropsychiatric SLE.

The rat brain astrocyte cell line RBA-1 was a gift from Dr T C Jou (Institute of Neuroscience, National Yang-Ming Medical College, Taipai, Taiwan, Republic of China). We are indebted to Miss Tzu-Miao Lin and Miss Yi-Sheng Chen for their excellent Miss Tzu-Miao Lin and Miss Yi-Sheng Chen for their excellen echnical assistance. We are also grateful to Miss Chia-Lin Leu for typing the manuscipt. This work is supported by grants from Sciences, Academia Sinica, Republic of China.

1 Johnson R T, Richardson E P. The neurological manifestations of systemic lupus erythematosus: a clinical-pathological study of 24 cases and review of the literature. Medicine (Balitimore) 1968; 47: 337-69.

2 Ellis S G, Verity M A. Central nervous system involvement in systemic lupus erythematosus: a review of neuropathological findings in 57 cases, 1955-1977. Semin Arthitis Rheum 1979; 8: 212-20.

3 Bluestein H G, Zvaifler N J. Brain-reactive lymphocytotoxic antibodies in the serum of patients with systemic lupus antibodies in the serum of patients with sy
erythematosus. 7 Clin Invest 1976; 57: 509-16.

4 Bresnihan B, Oliver M, Grigor G, Hughes G R F. Brain reactivity of lymphocytotoxic antibodies in systemic lupus erythematosus with and without cerebral involvement. Clin Exp Immunol 1977; 30: 333-7.

5 Bluestein H G, Williams G W, Steinberg A D. Cerebrospinal fluid antibodies to neuronal cells: association with neuropsychiatric manifestation of systemic lupus erythematosus. Am f Med 1981; 70: 240-6.

6 How A, Dent P B, Liao S-K, Denburg J A. Antineuronal antibodies in neuropsychiatric systemic lupus erythematosus. Arthritis Rheum 1985; 28: 789-95.

7 Robbins M L, Kornguth S E, Bell C L, et al. Antineurofilament antibody evaluation in neuropsychiatric systemic ment antibody evaluation in neuropsychiatric systemic assay and magnetic resonance imaging. Arthritis Rheum assay and magn

8 Bell C L, Partington C, Robbins M, et al. Magnetic resonance imaging of central nervous system lesions in patients with lupus erythematosus: correlation with clinical remission and anti-neurofilament and anti-cardiolipin antibody titers. Arthritis Rheum 1991; 34: 432-40.

9 Hirano T, Hashimoto H, Shiokawa Y, et al. Anti-glycolipid autoantibody detected in the sera from systemic lupus erythematosus patients. F Clin Invest 1980; 66: 1437-40.

10 Love P E, Santoro S A. Antiphospholipid antibodies: anticardiolipin and the lupus anticoagulant in systemic lupus erythematosus (SLE) and in non-SLE disorders. Ann Intern Med 1990; 112: 682-98. 
11 Asherson R A, Khamashta M A, Gil A, et al. Cerebrovascular disease and antiphospholipid antibodies in systemic lupus erythematosus, lupus-like disease and the primary antiphospholipid syndrome. Am J Med 1989; 86: 391-9.

12 Levine S R, Welch K M A. Cerebrovascular ischemia associated with lupus anticoagulant. Stroke 1987; 18: 257-63.

13 Fisher $M$, McGehee W. Cerebral infarct, TIA, and lupus inhibitor. Neurology 1986; 36: 1234-7.

14 Hart R G, Miller V T, Coull B M, Bril V. Cerebral infarction associated with lupus anticoagulants-preliminary report. Stroke 1984; 15: 114-8.

15 Field R A, Sibbitt W L, Toubbeh H, Bankhurst A D. Neuropsychiatric lupus erythematosus, cerebral infarctions, and
anticardiolipin antibodies. Ann Rheum Dis 1990; 49: 114-7.

16 Colaco C B, Scadding G, Newson-Davis J. Anti-cardiolipin antibodies in neurological diseases. Lancet 1985; i: 164 .

17 Levine S R, Welch K M A. The spectrum of neurologic disease associated with antiphospholipid antibodies. Arch Neurol 1987; 44: 876-83.

18 Bridley D P, Coull B M, Goodnight S H. Neurologica diseases associated with anti-phospholipid antibodies. An Neurol 1989; 25: 221-7.

19 Lolli F, Mata S, Baruffi M C, Amaducci L. Cerebrospinal fluid anti-cardiolipin antibodies in neurological diseases. Clin Immunol Immunopathol 1991; 59: 314-21.

20 Misra R, Venables P J W, Plater-Zyberk C, Watkins P F Maini R N. Anti-cardiolipin antibodies in infectious mononucleosis react with the membrane of activated lymphonucleosis react with the membrane of

21 Yu C-L, Sun K-H, Tsai C-Y, Wang S-R. Inhibitory effects of anticardiolipin antibodies on lymphocyte proliferation and anticardiolipin antibodies on lymphocyte proliferation and

22 Harris E N, Gharari A E, Tincani A, et al. Affinity purified anticardiolipin and anti-DNA antibodies. $f$ Clin Lab Immunol 1985; 17: 155-62.

23 Jou T C. Rat brain tissue cells in tissue culture. I. Ligh microscopic studies. Proc Natl Sci Counc Repub China [B] 1983; 7: 181-93.

24 Jou T C, Akimoto K. Rat brain tissue cells in tissue culture. II. Immunocytochemical staining of astrocytes in monolayer culture using antiserum to glial fibrillary acidic protein. Proc Natl Sci Counc Repub China [B] 1983; 7 . 488-95.
25 Jou T C, Jou M J, Chen J Y, Lee S Y. Properties of rat brain astrocytes in long-term culture. Fournal of the Formosan astrocytes in long-term culture. Fo
Medical Association 1985; 84: 865-81

26 Shapiro H M, Natale P J, Kamentsky L A. Estimation of membrane potentials of individual lymphocytes by flow cytometry. Proc Natl Acad Sci USA 1979; 76: 5728-30.

27 Bluestein H G, Pischel K D, Woods V L Jr. Immunopathogenesis of the neuropsychiatric manifestations of systemic lupus erythematosus. Semin Immunopathol 1986: 237-49.

28 Minota S, Koyasu S, Yahara I, Winfield J. Autoantibodies to the heat shock protein hsp90 in systemic lupus erythematosus. $\mathcal{F}$ Clin Invest 1988; 81: 106-9.

29 Khamashta M A, Harris E N, Gharavi A E, et al. Immune mediated mechanism for thrombosis: anti-phospholipid antibody binding to platelet membranes. Ann Rheum Dis antibody binding

30 Schorer A E, Wickham N W R, Watson K V. Lupus anticoagulant induces a selective defect in thrombin-mediated
endothelial prostacyclin release and platelet aggregation. $\mathrm{Br}$ endothelial prostacyclin release

31 Dostal-Johnson D, Rote N S, Branch D W. IgGl and IgG are the predominant subclasses of antiphospholipid antibody in women with the lupus anticoagulant. Clin Immuno Immunopathol 1990; 54: 309-19.

32 Hert\% L, McFarlin D E, Waksman B H. Astrocytes: auxiliary cells for immune responses in the central nervous system Immunol Today 1990; 11: 265-8.

33 Harris E N, Gharavi A E, Mackworth-Young C G, Patel B M Devue G, Hughes G R V. Lupoid sclerosis: a possible pathogenetic role for antiphospholipid antibodies. Ann Rheum Dis 1985; 44: 281-3.

34 Winfield J B, Shaw M, Silverman L M, et al Intrathecal IgG synthesis and blood brain barrier impairment in patients
with systemic lupus erythematosus and central nervous with systemic lupus erythematosus and central

$35 \mathrm{Z}$ hang $\mathrm{N} Z$, Chen $\mathrm{W} Z$. Antineuronal antibodies in Chinese patients with neuropsychiatric systemic lupus erythematosus (NP-SLE). Proceedings of the second international conference on systemic lupus erythematosus; 1989 Nov 26-30 Singapore. 1989: 109-11.

36 Tsai C-Y, Wu T-H, Sun K-H, Yu C-L. Effects of antibodies to double stranded DNA purified from serum samples of patients with active systemic lupus eryth glomerular mesangial cells. Ann Rheum Dis 1992;51: 162-7. 